\title{
Influence of immersion on respiratory requirements during 30-min cycling exercise
}

\author{
P-H. Bréchat*, J-P. Wolf*, M-L. Simon-Rigaud ${ }^{+}$, N. Bréchat \\ J-P. Kantelip ${ }^{+}$, S. Berthelay*, J. Regnard*
}

Influence of immersion on respiratory requirements during 30-min cycling exercise. $P-H$. Bréchat, J-P. Wolf, M-L. Simon-Rigaud, N. Bréchat, J-P. Kantelip, S. Berthelay, J. Regnard. (C) ERS Journals Ltd 1999.

ABSTRACT: Immersion is considered to facilitate exercise-based rehabilitation. However, the drag effect of moving limbs in water, likely to increase the respiratory requirements at exercise, is not mentioned in many reports.

The energetic and ventilatory requirements of $30 \mathrm{~min}$ steady state cycling exercise performed by healthy male subjects in air and during immersion up to the xiphoid in $33{ }^{\circ} \mathrm{C}$ water were compared.

In the first experimental series nine subjects exercised at the same $60 \%$ maximal oxygen consumption $\left(V^{\prime} \mathrm{O}_{2}\right.$, max $)$ in air and water. In the two ambient conditions, ventilatory variables had similar values, but the ergometric setting had to be reduced during water immersion so that the workload rated only $69 \pm 20 \mathrm{~W}($ mean \pm SD) in water versus $121 \pm 32 \mathrm{~W}(\mathrm{p}<0.001)$ in air. In the second experimental series, the same ergometric work load $(122 \mathrm{~W})$ was achieved by nine subjects with an average $V^{\prime} \mathrm{O}_{2}$ of $2,210 \pm 300 \mathrm{~mL} \cdot \mathrm{min}^{-1}$ in air versus $2,868 \pm 268 \mathrm{~mL} \cdot \mathrm{min}^{-1}$ in water $(\mathrm{p}<0.001)$. Resting water immersion caused a marked trend for decreasing vital capacity $(p=0.06)$, but no modification of other ventilatory variables. During exercise at similar $V^{\prime} \mathrm{O}_{2}$, the average values of minute ventilation $\left(V^{\prime} E\right)$, tidal volume $\left(V_{T}\right)$, respiratory frequency $(f \mathrm{R})$, tidal inspiratory time $(V \mathrm{~T} / \mathrm{t} \mathrm{I})$ were not different between water and air. However, at similar ergometric workload, $V^{\prime} \mathrm{E}, V \mathrm{~T}, f \mathrm{R}, V \mathrm{~T} / \mathrm{tI}$ and plasma lactate levels were significantly higher in water than in air. Such consequences of the drag effect of water upon limb movements have not been reported in previous studies relying on shorter exercise bouts.

Thus, maintaining steady exercise levels in water either led to a decrease in the workload or required a $\mathbf{2 5 \%}$ higher oxygen consumption than in air. These findings may be relevant to the prescription of water immersion rehabilitation programmes. Eur Respir J 1999; 13: 860-866.

During head out water immersion, the external hydrostatic pressure changes both haemodynamics and ventilatory mechanics. The peripheral vascular capacitance is diminished by the surrounding hydrostatic pressure while venous return and thoracic blood volume are increased, and systemic vascular resistance decreased $[1,2]$. Apart from the beneficial effects of cardiac filling and peripheral blood distribution [3], immersion is likely to burden ventilatory workload for two reasons. Firstly, the larger pulmonary blood volume stiffens pulmonary tissue, and the lowered lung compliance requires a larger ventilatory effort [4-6]. Secondly, while the pressure in the airways remains atmospheric, the pressure of the water surrounding the abdomen and the thorax is higher, which shifts the diaphragm cephalad $[4,7]$, increases transthoracic pressure, and decreases lung residual functional capacity and vital capacity (VC) $[4,8-10]$. All these conditions are graded by immersion level [11-13] and may burden ventilatory function at rest or during exercise $[4,14,15]$. Conversely, immersion also places inspiratory muscles at some mechanical advantage at rest, reducing their activation [16]. How immersion-related conditions actually affect ventilatory and
*Physiologie, Faculté de Médecine, Besançon, France. ${ }^{+}$Explorations fonctionnelles respiratoires, Faculté de Médecine, Besançon, France. 'Médecine interne-Gériatrie, Centre Hospitalier Général de Belfort, Belfort, France.

Correspondence: J. Regnard

Laboratoire de Physiologie

Faculté de Médecine

Place St Jacques

F-25030 Besançon

France

Fax: 33381668532

Keywords: Exercise immersion

oxygen consumption rehabilitation

ventilatory requirements

Received: June 41998

Accepted after revision November 171998

This study was supported in part by a grant from the Direction des Recherches et Etudes Doctorales. metabolic requirements for exercise remains unknown. However, physical training in water is proposed for cardiopulmonary rehabilitation and these procedures are considered to be safe, although the immersion-induced constraints have not been assessed [17]. In the present study, the ventilation and respiration-related energetics were studied before and during a cycling exercise, carried out both in ambient air and during immersion up to the xyphoid process, and performed either at an identical oxygen consumption $\left(V^{\prime} \mathrm{O}_{2}\right)$ (series 1$)$ or at an identical ergometric workload (series 2).

\section{Subjects and methods}

\section{Subjects}

Fifteen healthy male subjects participated in the study. Three subjects were involved in both series 1 and 2. All had a negative history of hypertension, pulmonary, cardiovascular or kidney diseases. Informed consent was obtained after the subjects had received a complete explanation 
of the experimental protocol as approved by the ethics committee. The main characteristics of the subjects, including maximal oxygen consumption $\left(V^{\prime} \mathrm{O}_{2}\right.$, max $)$ are given in table 1. All the subjects abstained from sustained exercise, smoking, and drinking coffee, tea, alcohol or taking any medications during the experiment.

\section{General organization of the study}

Series 1 and 2. In each series, the subjects had to cycle for two 30-min stints in ambient air and in water, seven days apart, in random order. In series 1, during the immersed exercise, the mechanical load of the ergocycle was adjusted to maintain the same $V^{\prime} \mathrm{O}_{2}$ as during air exercise, chosen at $60 \%$ of the previously determined $V^{\prime} \mathrm{O}_{2}$, max. In series 2 , during immersed exercise, the subjects were continuously encouraged to accomplish the same constant, fixed mechanical load on the ergocycle, as during air exercise.

Exercise in air was carried out at a room temperature of $25 \pm 2^{\circ} \mathrm{C}$ and water exercise took place in a rehabilitation pool with a water temperature of $33 \pm 0.2^{\circ} \mathrm{C}$, which is considered neutral temperature for exercising in water [11, 14]. A lead diver's belt ( $2 \mathrm{~kg}$ ) was buckled loosely around the waist to oppose the buoyancy effect of the water during immersed experiments, and the subject's feet were strapped to the pedals.

Assessment of maximal oxygen consumption. An incremental exercise was performed to assess each subject's $V^{\prime} \mathrm{O}_{2}$,max in air. The ergometric workload was first increased by $50 \mathrm{~W}$ every $5 \mathrm{~min}$, then $10 \mathrm{~W}$ every $3 \mathrm{~min}$ after passing the first ventilatory threshold, i.e. the point where the displayed traces of $10 \mathrm{~s}$ averaged minute ventilation $\left(V^{\prime} \mathrm{E}\right)$ and $V^{\prime} \mathrm{O}_{2}$ began to diverge.

Experimental session. In each experiment the following procedure was followed (fig. 1). At 07:30 h, the subject had a controlled meal $(4,200 \mathrm{~kJ}$ and $125 \mathrm{~mL}$ Volvic $(\mathrm{R})$ natural water). At 09:30 h, the subject emptied their bladder and settled down in a comfortable seated position. The subject was then wired up for thoracic impedance recordings and a catheter was inserted into a forearm vein. After $30 \mathrm{~min}$ of sitting at rest (time -5), the subject sat on the ergocycle in air or in water, donned the facial mask for ventilatory measurements

Table 1. - Main characteristics of subjects in series 1 (exercise at similar oxygen consumption $\left(V^{\prime} \mathrm{O}_{2}\right)$ in air and water; $n=9$ ) and 2 (exercise at similar ergometric workload in air and water; $n=9$ )

\begin{tabular}{lcc}
\hline & \multicolumn{1}{c}{ Series 1} & Series 2 \\
\hline Age yrs & $30 \pm 8(21-44)$ & $29 \pm 8(20-44)$ \\
Height cm & $182 \pm 8.0(170-192)$ & $182 \pm 7.4(170-192)$ \\
Weight kg & $74.1 \pm 7.6(66-83)$ & $74 \pm 7.1(66-83)$ \\
Body surface & $1.94 \pm 0.1(1.77-2.13)$ & $1.95 \pm 0.12(1.77-2.13)$ \\
$\quad$ area m & & \\
Body fat & $15.6 \pm 4.1(11.5-20.5)$ & $14.1 \pm 2.59(11.5-19)$ \\
index \% & & \\
$V^{\prime} \mathrm{O}_{2}$, max & $51.0 \pm 5.3(43-57.3)$ & $50.4 \pm 5.4(43-57.3)$ \\
$\mathrm{mL} \cdot \mathrm{min} \cdot \mathrm{kg}^{-1}$ & & \\
\hline
\end{tabular}

Data are presented as mean $\pm \mathrm{SD}$; figures in parentheses represent ranges. $V^{\prime} \mathrm{O}_{2}$, max: maximal $V^{\prime} \mathrm{O}_{2}$.

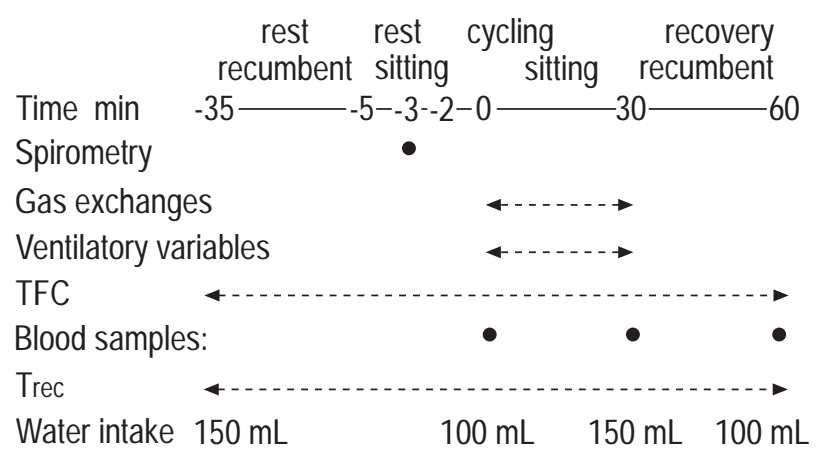

Fig. 1. - Time schedule of each session. TFC: thoracic fluid conducductivity; Trec: rectal temperature; $\bullet$ : time point at which parameter was measured; - - . - : duration of measurement.

and had a 5-min rest period for baseline measurements before starting (time 0 ) the $30 \mathrm{~min}$ exercise bout. At the end of exercise (time 30), the subject rested for 30 min in air (recovery until time 60). The subject was given $125 \mathrm{~mL}$ Volvic $(\mathrm{R})$ natural water to drink before the initial rest period and at the time of blood and urine samples, i.e. after rest (time -5), after cycling exercise (time 30) and after recovery (time 60).

\section{Techniques}

Immersible ergocycle. An immersible ergocycle was designed in the authors' laboratory and manufactured by Tecmachine (Andrézieux-Bouthéon, France). This ergocycle is equipped with an immersible power torque on which work intensity was electronically controlled.

Respiratory variables. Respiratory function of the subjects at rest was assessed while they were wearing the facial mask, i.e. during the 5-min of baseline rest and the 30 -min of exercise.

Spirometric variables. VC, forced expiratory volume in one second (FEV1), FEV1/VC, peak expiratory flow (PEF), maximal expiratory flow at 50 and $25 \% \mathrm{VC}$ (MEF50\% and MEF25\%) were measured during the baseline rest period. $V^{\prime} \mathrm{E}$, tidal volume $(V \mathrm{~T})$, breathing frequency $(f \mathrm{R})$, inspiratory time $(t \mathrm{I})$ and expiratory time $(t \mathrm{E})$ were measured during baseline rest and the 30-min exercise period. All these variables were measured with a pneumotachograph (CPF, Electronic Medical MSE, Strasbourg, France) and $V \mathrm{~T} / t \mathrm{I}, V \mathrm{~T} / \mathrm{VC}$ were calculated later.

Energetic variables. $V^{\prime} \mathrm{O}_{2}$ and carbon dioxide output $\left(V^{\prime} \mathrm{CO}_{2}\right)$ were measured with an zirconium oxygen analyser and with a rapidly responding infra-red carbon dioxide analyser (MGC 2001 CAD/NET, Electronic Medical MSE, Strasbourg, France), both of which were calibrated before and after each test. Respiratory quotient (R) and the respiratory oxygen equivalent $\left(V^{\prime} \mathrm{E} / V^{\prime} \mathrm{O}_{2}\right)$ were calculated from the raw data of oxygen and carbon dioxide tensions.

Additional variables. During each exercise session changes in thoracic fluid conductivity (TFC) were continuously measured from thoracic electrodes connected to a 
bioimpedance monitoring system (NCCOM3 model, version R7 software, Bomed Medical Manufacturing, Irvine, CA, USA). TFC represents the steady-state component of bioimpedance or total impedance (resistance to the high frequency alternating current measurement) of the thorax and depends on the quantity of fluids present within the thorax $[18,19]$.

Venous blood samples were immediately placed on ice and centrifuged within $10 \mathrm{~min}$ at $1,110 \times \mathrm{g}$ at $4^{\circ} \mathrm{C}$. Plasma lactate concentrations were determined by an enzymatic method (Boehringer Mannheim, Meylan, France).

Rectal temperature was monitored every $2 \mathrm{~min}$ from time -35 to time 60, with an YSI \# 401 thermistor (Yellow Spring Instrument, OH, Yellow Springs, USA) inserted 15 $\mathrm{cm}$ into the rectum.

\section{Statistical analysis}

The data were analysed (PCSM 6.0, DeltaSoft, Meylan, France) by a multifactorial analysis of variance (ANOVA) with repeated measures. Differences between mean values at the different times were tested with a post hoc multiple range test for repeated measures, and differences between mean values in the two series were tested with a post hoc multiple range test for independent measures (NewmanKeuls). Data are presented as mean \pm SD.

\section{Results}

\section{Baseline periods}

At baseline (table 2), respiratory indexes of whole body metabolism $\left(V^{\prime} \mathrm{O}_{2}, V^{\prime} \mathrm{CO}_{2}, V^{\prime} \mathrm{E} / V^{\prime} \mathrm{O}_{2}\right.$, and $\left.\mathrm{R}\right)$ showed no differences in water and air. Also $V \mathrm{~T}, f \mathrm{R}, t \mathrm{I}, t \mathrm{E}, \mathrm{FEV} 1$, FEV1/VC, PEF, MEF50\% and MEF25\% were similar in air and water in both series. There was a trend for a lower VC in water than air $(\mathrm{p}=0.06)$. TFC was similar for both ambient air series but rose markedly when the subjects entered the water $(\mathrm{p}<0.01)$. Lactate concentrations and rectal temperature were similar at baseline in air and water.

\section{Cycling at similar levels of oxygen consumption in air and water (series 1)}

Ergometric work. The ergometric work was kept constant during air exercise, but was reduced throughout immersed exercise in order to keep $V^{\prime} \mathrm{O}_{2}$ steady. During water exercise, the ergometric work was significantly lower after 16 min than at the onset of exercise. During the last 14 min of exercise, the group average ergometric work was lower in water than in air $(81.5 \pm 21.1 \mathrm{~W}$ versus $117.8 \pm 29.6 \mathrm{~W}$ respectively; $\mathrm{p}<0.01$; fig. 2 ).

Oxygen consumption. During exercise in air, $V^{\prime} \mathrm{O}_{2}$ increased until the second minute and then remained steady at about $2,100 \mathrm{~mL} \cdot \mathrm{min}^{-1}$ or $57 \% \mathrm{~V}^{\prime} \mathrm{O}_{2}$, max (table 3 and fig. 2). During exercise in water, the steady state $V^{\prime} \mathrm{O}_{2}$ was also achieved after 2 min at a mean value of $2,100 \mathrm{~mL} \cdot \mathrm{min}^{-1}$ or $59 \% V^{\prime} \mathrm{O}_{2}$, max (table 3 and fig. 2). Thus, there was no difference in steady state $V^{\prime} \mathrm{O}_{2}$ during air or immersed exercise.

Ventilatory variables. During exercise in air, $V^{\prime} \mathrm{CO}_{2}$ and $\mathrm{R}$ increased to a steady state achieved after 6 and 4 min respectively, while $V^{\prime} \mathrm{E} / V^{\prime} \mathrm{O}_{2}$ decreased to a steady state after 2 min. $V$ T and $V \mathrm{~T} / t \mathrm{I}$ achieved a steady state after 4 min and $V^{\prime} \mathrm{E}$ after $6 \mathrm{~min}$, while $t \mathrm{I}$ and $t \mathrm{E}$ decreased and stabilized after 4 min (table 3; figs. 2, 3 and 4).

During exercise in water, $V^{\prime} \mathrm{CO}_{2}$ and $\mathrm{R}$ reached a steady state at 4 and $8 \mathrm{~min}$, respectively, and $V^{\prime} \mathrm{E} / V^{\prime} \mathrm{O}_{2}$ at $6 \mathrm{~min}$.

Table 2. - Resting values of spirometry, respiratory and energetic variables in series 1 (exercise at similar oxygen consumption $\left(V^{\prime} \mathrm{O}_{2}\right)$ in air and water) and in series 2 (exercise at similar ergometric workload in air and water)

\begin{tabular}{|c|c|c|c|c|}
\hline & \multicolumn{2}{|c|}{ Series 1} & \multicolumn{2}{|c|}{ Series 2} \\
\hline & Air & Water & Air & Water \\
\hline TFC $10^{2} \cdot \Omega^{-1}$ & $39 \pm 4$ & $47 \pm 3 *$ & $40 \pm 3$ & $50 \pm 5^{*}$ \\
\hline $\mathrm{VC} \mathrm{L}$ & $5.78 \pm 0.77$ & $5.21 \pm 0.49^{+}$ & $5.66 \pm 0.72$ & $5.09 \pm 0.58^{+}$ \\
\hline FEV1 L & $4.5 \pm 0.8$ & $4 \pm 0.7^{+}$ & $4.7 \pm 0.6$ & $4.2 \pm 0.6^{+}$ \\
\hline $\mathrm{PEF} \mathrm{L} \cdot \mathrm{s}^{-1}$ & $10.4 \pm 2.2$ & $10.1 \pm 2.2$ & $11.7 \pm 1.6$ & $11.4 \pm 1.7$ \\
\hline MEF $50 \% \mathrm{~L} \cdot \mathrm{s}^{-1}$ & $4.8 \pm 1.9$ & $4.3 \pm 1.9$ & $5.7 \pm 1.6$ & $5.1 \pm 1.7$ \\
\hline $\mathrm{MEF} 25 \% \mathrm{~L} \cdot \mathrm{s}^{-1}$ & $2.1 \pm 1.1$ & $1.8 \pm 0.9$ & $2.7 \pm 1.1$ & $2.2 \pm 0.9$ \\
\hline$V \mathrm{~T} \mathrm{~mL}$ & $710 \pm 126$ & $854 \pm 163$ & $898 \pm 163$ & $738 \pm 166$ \\
\hline$f \mathrm{R}$ breaths $\cdot \min ^{-1}$ & $19 \pm 1$ & $17 \pm 3$ & $17 \pm 2$ & $21 \pm 4$ \\
\hline$V^{\prime} \mathrm{E} \mathrm{L} \cdot \mathrm{min}^{-1}$ & $12.8 \pm 2.5$ & $13.1 \pm 4.4$ & $15.1 \pm 3.3$ & $15.2 \pm 3.5$ \\
\hline$t \mathrm{I} \mathrm{S}$ & $1.4 \pm 0.2$ & $1.6 \pm 0.3$ & $1.6 \pm 0.2$ & $1.5 \pm 0.5$ \\
\hline$t \mathrm{E} \mathrm{s}$ & $1.8 \pm 0.4$ & $2.0 \pm 0.3$ & $2.1 \pm 0.3$ & $1.7 \pm 0.4$ \\
\hline$V \mathrm{~T} / t \mathrm{I} \mathrm{mL}$ & $495 \pm 127$ & $494 \pm 127$ & $560 \pm 133$ & $538 \pm 154$ \\
\hline$V \mathrm{~T} / \mathrm{VC}$ (air) & $0.13 \pm 0.02$ & $0.13 \pm 0.03$ & $0.16 \pm 0.03$ & $0.14 \pm 0.03$ \\
\hline$V^{\prime} \mathrm{O}_{2} \mathrm{~mL} \cdot \mathrm{min}^{-1}$ & $315 \pm 59$ & $311 \pm 62$ & $368 \pm 77$ & $358 \pm 104$ \\
\hline$\% V^{\prime} \mathrm{O}_{2}, \max$ & $7.4 \pm 1.7$ & $8.4 \pm 3.6$ & $10.5 \pm 1.9$ & $9.9 \pm 3.1$ \\
\hline$V^{\prime} \mathrm{E} / V^{\prime} \mathrm{O}_{2}$ & $46 \pm 8$ & $42 \pm 7$ & $44 \pm 10$ & $44 \pm 10$ \\
\hline$V^{\prime} \mathrm{CO}_{2} \mathrm{~mL} \cdot \mathrm{min}^{-1}$ & $327 \pm 206$ & $299 \pm 154$ & $326 \pm 75$ & $330 \pm 90$ \\
\hline Respiratory quotient & $0.89 \pm 0.04$ & $0.97 \pm 0.08$ & $0.89 \pm 0.07$ & $0.92 \pm 0.07$ \\
\hline Trec ${ }^{\circ} \mathrm{C}$ & $37.4 \pm 0.2$ & $37.2 \pm 0.2$ & $37.2 \pm 0.2$ & $37.3 \pm 0.3$ \\
\hline Latacte $\mathrm{mg} \cdot \mathrm{L}^{-1}$ & $1.5 \pm 0.5$ & $1.5 \pm 0.4$ & $1.3 \pm 0.6$ & $1.04 \pm 0.2$ \\
\hline
\end{tabular}

Data are expressed as mean \pm SD. TFC: thoracic fluid conductivity; VC: vital capacity; FEV1: forced expiratory volume in one second; PEF: peak expiratory flow; MEF50\%, MEF $25 \%$ : maximal expiratory flow at 50 and $25 \% \mathrm{VC}$, respectively; $V \mathrm{~T}$ : tidal volume; $f \mathrm{R}$ : respiratory frequency; $V^{\prime} \mathrm{E}$ : minute ventilation; $t \mathrm{I}$ : inspiratory time; $t \mathrm{E}$ : expiratory time; $V^{\prime} \mathrm{CO}_{2}$ : carbon dioxide consumption; Trec: rectal temperature. ${ }^{*}: \mathrm{p}=0.06 ;{ }^{+}: \mathrm{p}=0.06$, differences between air and water in the same series. 

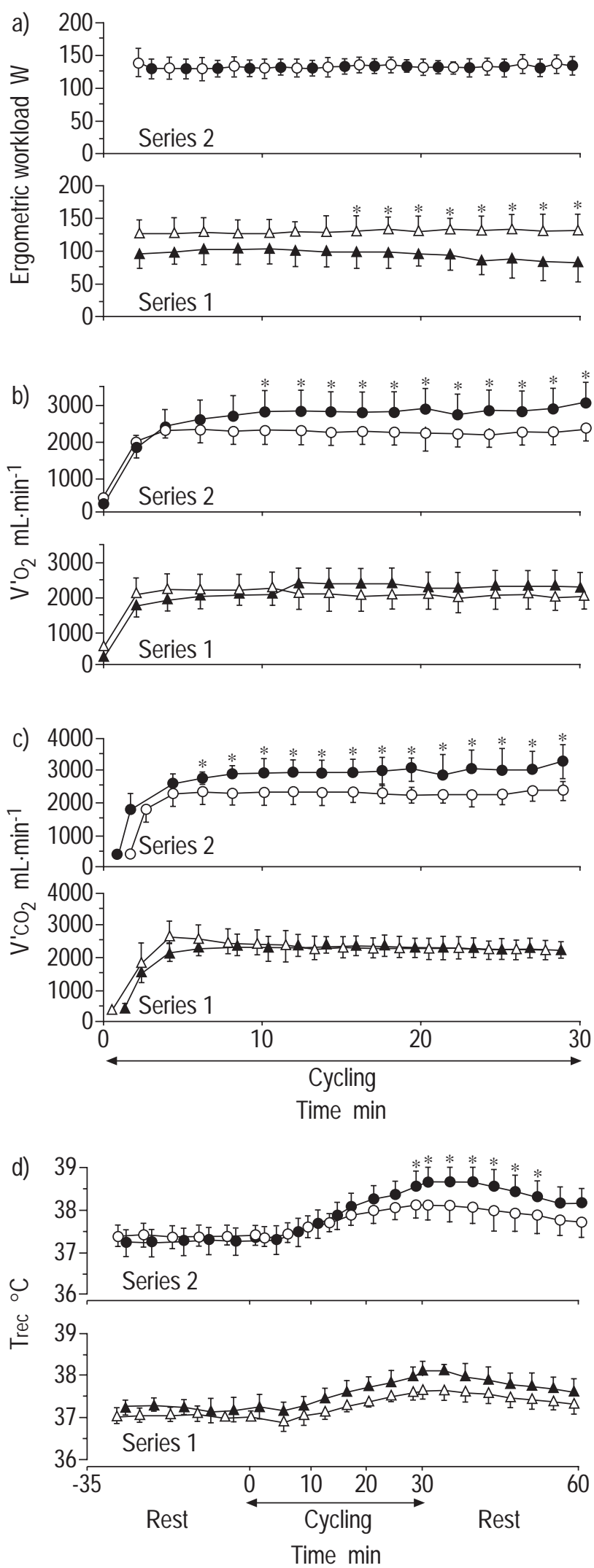

Fig. 2. - Changes over time in a) ergometric work, b) oxygen consumption $\left(V^{\prime} \mathrm{O}_{2}\right)$, c) carbon dioxide production $\left(V^{\prime} \mathrm{CO}_{2}\right)$, and d) rectal temperature (Trec) during air and water exercise in series 1 (same $V^{\prime} \mathrm{O}_{2}$ ) and series 2 (same ergometric work). $\triangle$ : exercise in air, series $1 ; \boldsymbol{\Delta}$ exercise in water, series $1 ; \bigcirc$ : exercise in air series 2 ; $\bullet$ : exercise in water, series $2 . *: \mathrm{p}<0.05$, difference between air and water exercise.
$V \mathrm{~T}$ and $V \mathrm{~T} / t \mathrm{I}$ achieved a steady state after 4 min and $f \mathrm{R}$ and $V^{\prime} \mathrm{E}$ after $6 \mathrm{~min}$, while $t \mathrm{I}$ and $t$ E reached steady state at 6 min. For all these variables, there were no differences at any time between air and water, but $V \mathrm{~T} / \mathrm{VC}$ in water was higher than $V \mathrm{~T} / \mathrm{VC}$ in air $(\mathrm{p}<0.01$, table 3$)$.

Additional variables. During exercise in the two ambient conditions, TFC was not modified and plasma lactate levels increased to the same extent (tables 2 and $3)$. Rectal temperature increased regularly during each exercise session $(\mathrm{p}<0.01)$ and decreased regularly afterwards but had not resumed pre-exercise values after 30 min recovery $(\mathrm{p}<0.05)$. No difference in rectal temperature between air and water exercise was recorded at any time (table 3 and fig. 2).

Cycling at the same ergometric work in air and water (series 2)

Ergometric work. As expected, a similar ergometric workload (approximately $120 \mathrm{~W}$ ) was achieved during air and water exercises (table 3 and fig. 2).

Oxygen consumption. During exercise in air, $V^{\prime} \mathrm{O}_{2}$ reached a steady state after $2 \mathrm{~min}$ at a mean value of $2,210 \mathrm{~mL} \cdot \mathrm{min}^{-1}$ or $61 \% V^{\prime} \mathrm{O}_{2}$, max (table 3, fig. 2). During exercise in water, $V^{\prime} \mathrm{O}_{2}$ increased regularly until $8 \mathrm{~min}$ of exercise, remained transiently steady until $24 \mathrm{~min}$ before rising again slowly till the end of exercise (table 3 and fig. 2). Thus, in water, the average $V^{\prime} \mathrm{O}_{2}$ progressively shifted from 2,285 to 2,927 $\mathrm{mL} \cdot \mathrm{min}^{-\mathrm{P}}$ between 24 to $30 \mathrm{~min}(\mathrm{p}<0.01)$, or from 61 to $80 \% V^{\prime} \mathrm{O}_{2}$, max. As a result, $V^{\prime} \mathrm{O}_{2}$ was significantly higher $(\mathrm{p}<0.01)$ during water exercise in series 2 than in the three other conditions from 8-30 min of exercise (table 3 ).

Ventilatory variables. Steady state $V^{\prime} \mathrm{CO}_{2}$ was achieved after $4 \mathrm{~min}$ in air and after $8 \mathrm{~min}$, although at a significantly higher level, in water $(\mathrm{p}<0.001$; table 3 ; fig. 2$)$. $V^{\prime} \mathrm{E}$ was stable after $4 \mathrm{~min}$ in air, and at a higher level after $12 \mathrm{~min}$ in water $(\mathrm{p}<0.001$; table 3 ; fig. 3 ). Also $V \mathrm{~T}$ and $V \mathrm{~T} / t \mathrm{I}$ were higher and reached a steady state later in water than air $(\mathrm{p}<0.001$; table 3 ; figs. 3 and 4$) . V T$ encompassed a larger part of VC (air) during water exercise than during air exercise $(\mathrm{p}<0.05$; table 3$)$.

Additional variables. TFC was not changed, and plasma lactate increased with exercise and was higher at the end of water exercise than at the end of air exercise $(\mathrm{p}<$ 0.001 , tables 2 and 3). Rectal temperature increased similarly during the first 15 min of exercise in the two ambient conditions, and thereafter more in water than in air $(p<0.01$, table 3; fig. 2). During recovery after water exercise, rectal temperature remained at a plateau for the first 10 min before declining, but decreased immediately after air exercise.

\section{Discussion}

It was observed that during a 30-min exercise performed by healthy subjects, the ergometric power achieved during immersion up to the xiphoid, was only $60 \%$ of the power achieved in air at the same $V^{\prime} \mathrm{O}_{2}$. Also, to achieve the same 
Table 3. - Respiratory and energetic variables during steady-state exercise in air and water, in series 1 (similar oxygen consumption $\left(V^{\prime} \mathrm{O}_{2}\right)$ ) and in series 2 (similar ergometric workload)

\begin{tabular}{|c|c|c|c|c|}
\hline & \multicolumn{2}{|c|}{ Series 1} & \multicolumn{2}{|c|}{ Series 2} \\
\hline & Air & Water & Air & Water \\
\hline $\operatorname{TFC} 10^{2} \cdot \Omega^{-1}$ & $39 \pm 5$ & $47 \pm 4^{*}$ & $39 \pm 4$ & $51 \pm 6^{*}$ \\
\hline$V \mathrm{~T} \mathrm{~mL}$ & $2229 \pm 390$ & $2291 \pm 381$ & $2213 \pm 327$ & $2564 \pm 399(4) * * *$ \\
\hline$f \mathrm{R}$ breaths $\cdot \min ^{-1}$ & $30 \pm 4$ & $27 \pm 5$ & $28 \pm 4$ & $35 \pm 6(12)^{* * *}$ \\
\hline$V^{\prime} \mathrm{E} \mathrm{L} \cdot \mathrm{min}^{-1}$ & $65.0 \pm 9.7$ & $61.5 \pm 9.6$ & $60.4 \pm 9.3$ & $90.3 \pm 18.5(14)^{* * *}$ \\
\hline$t \mathrm{I} \mathrm{s}$ & $0.9 \pm 0.1$ & $1.1 \pm 0.3$ & $1.0 \pm 0.2$ & $0.8 \pm 0.1(6)^{* * *}$ \\
\hline$t \mathrm{E} \mathrm{S}$ & $1.1 \pm 0.15$ & $1.2 \pm 0.21$ & $1.2 \pm 0.2$ & $0.9 \pm 0.1(8)^{* * *}$ \\
\hline$V \mathrm{~T} / t \mathrm{I} \mathrm{mL} \cdot \mathrm{s}^{-1}$ & $2382 \pm 367$ & $2208 \pm 407$ & $2204 \pm 4.13$ & $3153 \pm 762(14) * * *$ \\
\hline$V \mathrm{~T} / \mathrm{VC}$ (air) & $0.40 \pm 0.73$ & $0.36 \pm 0.71$ & $0.40 \pm 0.94$ & $0.45 \pm 0.32(2)^{*}$ \\
\hline$V \mathrm{~T} / \mathrm{VC}$ (water) & & $0.47 \pm 0.60 * *$ & & $0.51 \pm 0.12(8) * * *$ \\
\hline Ergometric workload W & $121 \pm 32$ & $69 \pm 20(16,30)^{* * *}$ & $123 \pm 10$ & $121 \pm 11^{\dagger}$ \\
\hline$V^{\prime} \mathrm{O}_{2} \mathrm{~mL} \cdot \mathrm{min}^{-1}$ & $2095 \pm 364$ & $2102 \pm 368^{\dagger}$ & $2210 \pm 300$ & $2868 \pm 268(8)^{* * *}$ \\
\hline$\% V^{\prime} \mathrm{O}_{2}, \max$ & $57 \pm 09$ & $59 \pm 08$ & $61 \pm 09$ & $79 \pm 12(8)^{* * *}$ \\
\hline$V^{\prime} \mathrm{E} / V^{\prime} \mathrm{O}_{2}$ & $31 \pm 5$ & $30 \pm 5$ & $28 \pm 3$ & $32 \pm 4.3(4) * * *$ \\
\hline$V^{\prime} \mathrm{CO}_{2} \mathrm{~mL} \cdot \mathrm{min}^{-1}$ & $2163 \pm 410$ & $2099 \pm 348$ & $2119 \pm 339$ & $2838 \pm 476(6) * * *$ \\
\hline Respiratory quotient & $0.92 \pm 0.06$ & $0.99 \pm 0.13$ & $0.88 \pm 0.09$ & $0.95 \pm 0.06(8) * * *$ \\
\hline Trec ${ }^{\circ} \mathrm{C}$ & $37.6 \pm 0.2$ & $37.6 \pm 0.1$ & $37.5 \pm 0.3$ & $38.0 \pm 0.4(28)^{* * *}$ \\
\hline Latacte $\mathrm{mg} \cdot \mathrm{L}^{-1}$ & $4.0 \pm 2.9$ & $3.4 \pm 1.6$ & $2.9 \pm 1.2$ & $8.1 \pm 2.8 * * *$ \\
\hline
\end{tabular}

Data are presented as mean \pm SD. For definitions see table 2. Values were averaged for steady state 2-30 min of exercise in air (series 1 and 2 ) and water (series 1 ). In water in series 2 , the beginning time of the steady state period are indicated in parentheses. $*$ : p<0.05; **: $\mathrm{p}<0.01 ; * * * \mathrm{p}<0.001$, for differences between air and water in the same series; ${ }^{\dagger}: \mathrm{p}<0.05$ for differences between the two series in the same conditions (air or water).

ergonomical workload in water than in air required approximately $130 \%$ of the $V^{\prime} \mathrm{O}_{2}$ used in air. Besides resulting in a larger energy expenditure, exercising in water also led to markedly larger ventilatory requirements.

At rest, water immersion up to the xiphoid caused a rise in thoracic fluid content as demonstrated by the larger thoracic fluid conductivity. This shift in plasma volume has been ascribed to the effect of hydrostatic pressure on the lower limbs and the abdomen [20]. A marked trend was observed for lower $\mathrm{VC}$ and $\mathrm{FEV} 1$ of subjects sitting on the ergocycle in water than in air. This $10 \%$ decrease of $\mathrm{VC}$ was consistent with previous reports $e . g$. by GREENE et al. [21]. However, during the same resting period $V^{\prime} \mathrm{O}_{2}, V^{\prime} \mathrm{E}$, $V \mathrm{~T}$ and $f \mathrm{R}$ were similar in water and air, in keeping with other observations during quiet immersion up to the neck $[16,22]$ and to the xiphoid level $[15,16]$. Conversely, during exercise, the energetic and ventilatory requirements were increased by immersion.

\section{Energetic requirements}

The same $V^{\prime} \mathrm{O}_{2}$ was required to achieve a lower ergometric workload in water than in air. Two lines of evidence led to this result since the workload setting had to be reduced in water to keep $V^{\prime} \mathrm{O}_{2}$ constant and $V^{\prime} \mathrm{O}_{2}$ rose in water when the ergometric setting was kept similar to that of the air exercise. Indeed, the additional $V^{\prime} \mathrm{O}_{2}$ (an average $28 \%$ of $V^{\prime} \mathrm{O}_{2}$, max) during the last 6 min of water exercise in series 2 was quite similar to the average reduction in ergometric workload (28\%) between air and water exercise in series 1 . In water during series 2 , the higher rectal temperature during the last minutes of exercise and recovery provided further evidence that energy expenditure was higher in water than in air. In addition, plasma lactate levels rose significantly more $(+122 \%$ versus $+67 \%)$ when the same ergometric workload was achieved in water.
Several groups reported similar $V^{\prime} \mathrm{O}_{2}$ values for exercise of short duration (between 5 and $15 \mathrm{~min}$ ) performed either at constant or increasing workload $(0-120 \mathrm{~W})$ in air and in water $\left(33^{\circ} \mathrm{C}\right)[10,13,17]$. However, the higher energetic cost of exercising in water was not repeatedly documented. Indeed, the larger energetic requirement in water for an ergometric workload identical to that in air depends mainly on water density, which is approximately 800-times the density of air. To displace water instead of air, the energetic cost of limb movements is thus greater. But, in previous studies, this energetic requirement was not found to be significantly greater in water. In series 2 , the $V^{\prime} \mathrm{O}_{2}$ difference between water and air exercise became significant only after $8 \mathrm{~min}$, consistent with the lack of any increase due to immersion reported by other studies of short exercise bouts. In the study by HALL et al. [23] with treadmill walking bouts lasting $5 \mathrm{~min}$, the $V^{\prime} \mathrm{O}_{2}$ became higher in water than in air at walking speeds of 4.5 and $5.5 \mathrm{~km} \cdot \mathrm{h}^{-1}$, but was not different at $3.5 \mathrm{~km} \cdot \mathrm{h}^{-1}$. In the same study, the perceived leg exertion (subjective rating) was greater in water than in air at every speed despite a markedly lowered stride frequency in water. During the present study, maintaining a steady cycling frequency in water required the subject to resist the spontaneous tendency to decrease pedalling pace and was achieved both by having the subject pay close attention to the timing and by continuous coaching, especially at the highest ergometric workload and $V^{\prime} \mathrm{O}_{2}$. Indeed, avoiding a significant drift of the pedalling frequency was necessary to maintain the calculated ergometric workload, i.e. the product of the braking couple by a constant rotation speed. A decrease in pedalling frequency would most likely reduce energy expenditure, and hence lessen any difference in $V^{\prime} \mathrm{O}_{2}$ between water and air exercise. Finally, besides coping with the drag effect of displacing water, the motor patterns also have to be adapted to cope with sensations associated with leg buoyancy. 

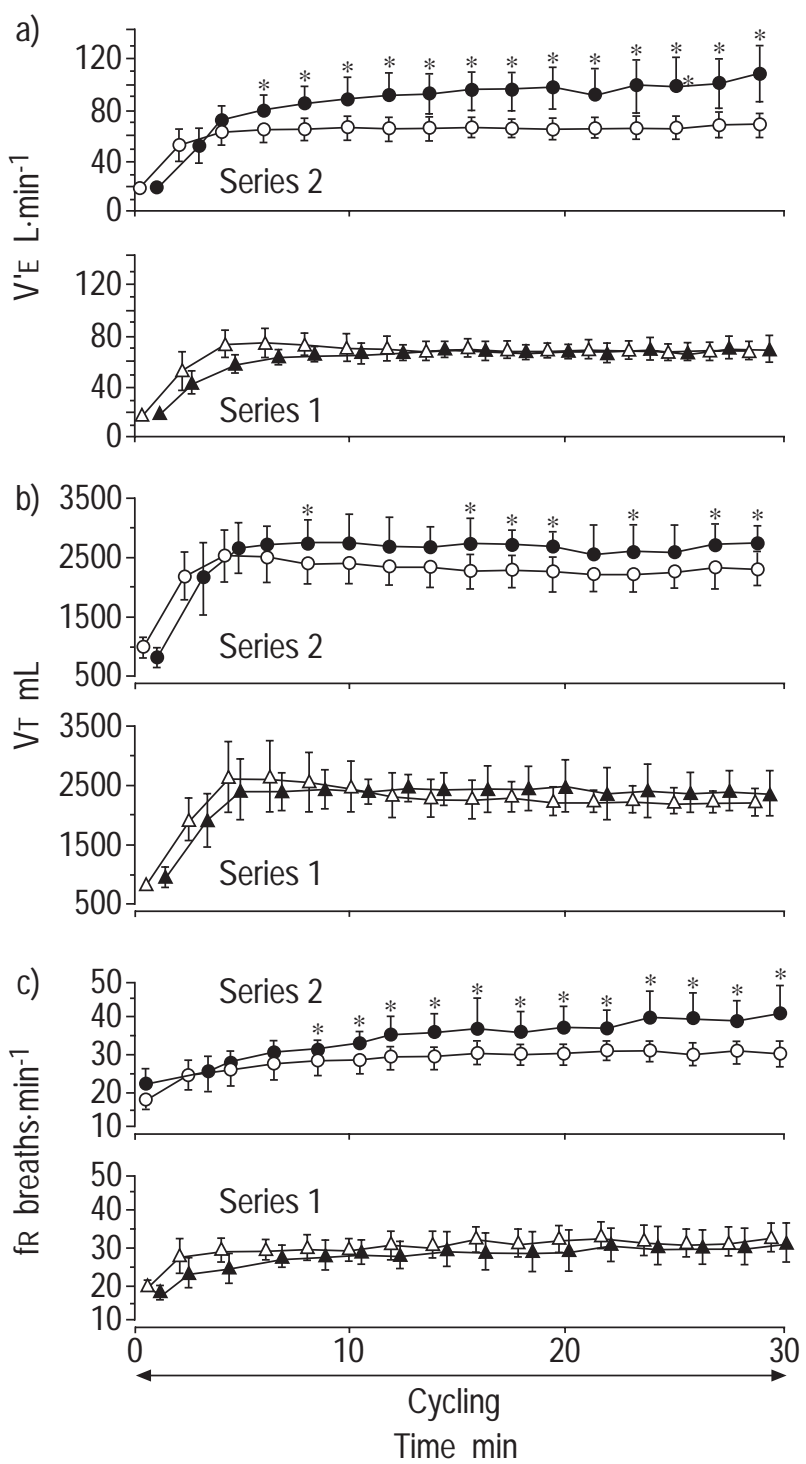

Fig. 3. - Changes over time in a) minute ventilation $\left(V^{\prime} \mathrm{E}\right)$, b) tidal volume $(V \mathrm{~T})$ and $\mathrm{c})$ breathing frequency $(f \mathrm{R})$ during air and water exercise in series 1 and $2 . \triangle$ : exercise in air, series $1 ; \boldsymbol{\Delta}$ : exercise in water, series 1 ; $\bigcirc$ : exercise in air series 2; $\bullet$ : exercise in water, series 2 .

Thus although the subject's perception of the drag impeding movement starts immediately with immersion, the measured evidence of the energetic aftermath is delayed.

\section{Ventilatory requirements during exercise}

Ventilatory variables $\left(V^{\prime} \mathrm{E}, V \mathrm{~T}, f \mathrm{R}\right)$ ranked similarly in water and air when oxygen consumption was similar, at approximately $60 \%$ of $V^{\prime} \mathrm{O}_{2}$, max (series 1 ). However, steady state values of ventilatory variables were reached later during water exercise. Despite the immersion-induced reduction in $\mathrm{VC}$ there was no difference in absolute $V \mathrm{~T}$ during exercise, although the ergometric workload accomplished in water was lower. The authors are not aware of other data collected in conditions similar to the present study. During very short periods $(5,3,1 \mathrm{~min})$ of cycling exercise at increasing work rates $(0-84 \mathrm{~W}) V^{\prime}$ E showed a similar increase in air and in water, but $f \mathrm{R}$ was higher and $V_{\mathrm{T}}$ lower
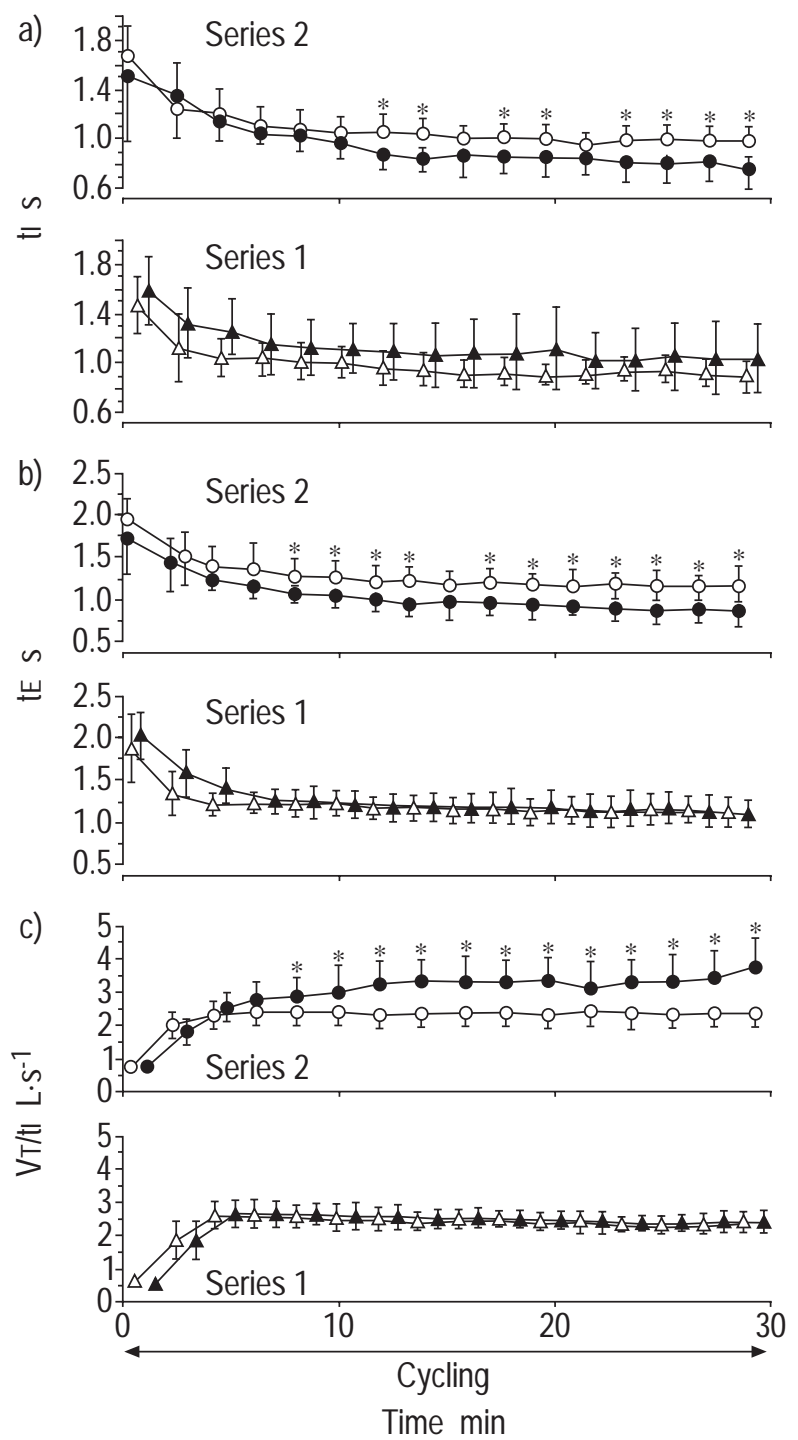

Fig. 4. - Changes over time in a) inspiratory time ( $t \mathrm{I}), \mathrm{b})$ expiratory time $(t \mathrm{E})$ and $\mathrm{c})$ tidal volume $(V \mathrm{~T}) / t \mathrm{I}$ during air and water exercise in series 1 and 2. $\triangle$ : exercise in air, series $1 ; \boldsymbol{\Delta}$ : exercise in water, series $1 ; \bigcirc$ : exercise in air series 2 ; $\bullet$ : exercise in water, series 2 .

in water than air [8]. The same observations have been made between 40 and $80 \%$ of $V^{\prime} \mathrm{O}_{2}$, max [15].

During the high-intensity water exercise in series 2 , the larger increases in $V^{\prime} \mathrm{E}, f \mathrm{R}$ and $V \mathrm{~T}$ were prompted by a larger production of carbon dioxide and lactate. Steady states were also reached later in water than in air, and in water later for $V^{\prime} \mathrm{E}$ and $f \mathrm{R}$ (12 and $14 \mathrm{~min}$, respectively) than $V \mathrm{~T}(4 \mathrm{~min})$. It is well known that establishing a steady state requires more time at higher work rates [24]. In water, the higher $V \mathrm{~T} / t \mathrm{I}$ reflected the larger ventilatory drive. It is also noteworthy that the ventilation requirements in water were met through a larger $V$ T which was an average $45 \%$ of $\mathrm{VC}$ (in air) or $51 \%$ of $\mathrm{VC}$ (in water). $V \mathrm{~T}$ values accounting for such a large part of VC are normally only found in strenuous exercise [25]. During immersion, the physical events causing the reduction of both $\mathrm{VC}$ and lung compliance might further extend the mechanical work of ventilation [4]. In three experimental conditions, the $f \mathrm{R}$ closely averaged $30 \mathrm{breath} \cdot \mathrm{min}^{-1}$, i.e. took place within the range 
of the pedalling frequency [26]. However, during series 2 in water, the large ventilatory performance could not be achieved by the sole increase of $V \mathrm{~T}$, and $f \mathrm{R}$ significantly exceeded the pedalling frequency. It can therefore be suspected that the large ventilatory work demonstrated by high values of $V \mathrm{~T} / t \mathrm{I}, V \mathrm{~T}$ and $f \mathrm{R}$ contributed to a higher $V^{\prime} \mathrm{O}_{2}$ in water than in air at similar ergometric workloads.

In conclusion, the study showed that in healthy subjects, immersion per se did not impair respiratory function at rest or during the first 4-8 min of moderate exercise. After the first few minutes and throughout the 30 min studied, immersion imposed an excess load on the chosen ergonomical workload, so that oxygen consumption was about $25 \%$ higher during cycling in water than in air. The ventilatory strain associated with performing large tidal volumes and high ventilatory frequencies may be increased by immersion-related burdens. Thus, during immersion, the heavy mechanical constraints caused by a large minute ventilation on congestive lungs might stress the alveolar capillary walls and favour the occurrence of pulmonary oedema in prone subjects $[27,28]$. It is therefore, submitted that consistent efforts in water should be proposed only for normal subjects, and that it might be wise to carefully consider the conditions under which rehabilitation programmes in water are safe for subjects with respiratory or cardiac impairments.

Acknowledgements. The authors thank the subjects who enthusiastically enrolled in the study, P. Vichard for the use of the rehabilitation pool, R. Candau, for helpful comments, and the expert technical assistance of J. Gototte, P. Jan, G. Martel, E. Miot, M. Siess, G. Toubin.

\section{References}

1. Gauer $\mathrm{OH}$, Thron I. Postural changes in the circulation In: Hamilton WF, ed. Handbook of Physiology. Circulation, Section 2, Vol III. Washington DC, American Physiology Society, 1965; pp. 2409-2439.

2. Arborelius MR, Baldin UI, Lilja B, Lundgren CEG. Hemodynamic changes in man during immersion with the head above water. Aerosp Med 1972; 43: 592-598.

3. Sheldhal LM, Wann LS, Clifford PS, Tristani FE, Wolf LG, Kalbfleich JH. Effect of central hypervolemia on cardiac performance during exercise. J Appl Physiol 1984; 57: 1662-1667.

4. Agostoni E, Gurtner G, Torri G, Rahn H. Respiratory mechanics during submersion and negative-pressure breathing. J Appl Physiol 1966; 21: 251-258.

5. Bondurant S, Mead J, Cook CD. A re-evalution of the effects of acute central congestion on pulmonary compliance in normal subjects. J Appl Physiol 1960; 15: 875-877.

6. Begin R, Epstein M, Sackner MA, Levinston R, Dougherty R, Duncan D. Effects of water immersion to the neck on pulmonary circulation and tissue volume in man. $J$ Appl Physiol 1976; 40: 293-299.

7. Greenleaf JE. Physiological responses to prolonged bed rest and fluid immersion in humans. J Appl Physiol 1984; 57: 619-633.

8. Craig AB, Ware DE. Effect of immersion in water on vital capacity and residual volume of the lungs. $J$ Appl Physiol 1967; 23: 423-425.

9. Taylor NAS, Morrisson JB. Lung volume changes in response to altered breathing gas pressure during upright immersion. Eur J Appl Physiol 1991; 62: 122-129.

10. Guyatt AR, Newman F, Cinkotai FF, Palmer JI, Thomson ML. Pulmonary diffusing capacity in man during immersion in water. J Appl Physiol 1965; 20: 878-881.

11. Fahri LE, Linnarsson D. Cardiopulmonary readjustment during graded immersion in water at $35^{\circ} \mathrm{C}$. Respir Physiol 1977; 30: 35-50.

12. Risch WD, Koubenec HJ, Beckmann V, Lange S, Gauer $\mathrm{OH}$. The effect of graded immersion on heart volume, central venous pressure, pulmonary blood dilution, and heart rate in man. Pflügers Arch 1978; 374: 115-118.

13. Craig AB, Dvorak M. Expiratory reserve volume and vital capacity of the lungs during immersion in water. $J$ Appl Physiol 1975; 38: 5-9.

14. McArdle WD, Magel JR, Lesmes GR, Pechar GS. Metabolic and cardiovascular adjustment to work in air and water at 18, 25 and $33^{\circ}$ C. $J$ Appl Physiol 1976; 40: 85-90.

15. Sheldhal IM, Tristani FE, Clifford PS, Hugues CV, Sobocinski KA, Morris RD. Effect of head-out water immersion on cardio-respiratory response to dynamic exercise. J Am Coll Cardiol 1987; 10: 1254-1258.

16. Reid LM, Banzett RB, Feldman HA, Mead J. Reflex compensation of spontaneous breathing when immersion changes diaphragm length. J Appl Physiol 1985; 58: 1136-1142.

17. Perk J, Perk L, Bodén C. Cardiorespiratory adaptation of COPD patients to physical training on land and in water. Eur Respir J 1996; 9: 248-252.

18. Kubicek WG, Patterson RP, Witsoe DA. Impedance cardiography as a noninvasive method of monitoring cardiac function and other parameters of cardiovascular system. Ann NY Acad Sci 1970; 170: 724-732.

19. Sramek BB. The impact on diagnosis and therapy of computerized integration, processing and display of noninvasive hemodynamic and cardiodynamic parameters. Intensive Care World 1989; 6: 205-210.

20. Johansen LB, Jensen TUS, Pump B, Norsk P. Contribution of abdomen and legs to central blood volume expansion in humans during immersion. $J$ Appl Physiol 1997; 83: 695-699.

21. Greene R, Hugues JMB, Suolow MF, Milic-Emili J. Regional lung volumes during water immersion to the xiphoid in seated man. $J$ Appl Physiol 1974; 36: 734-736.

22. Mekjavic B, Bligh J. The increased oxygen uptake upon immersion. Eur J Appl Physiol 1989; 58: 556-562.

23. Hall J, Macdonald IA, Maddison PJ, O'Hare JP. Cardiorespiratory responses to underwater treadmill walking in healthy females. Eur J Appl Physiol 1998; 77: 278-284.

24. Whipp BJ, Wasserman K. Oxygen uptake kinetics for various intensities of constant-load work. J Appl Physiol 1972; 33: 351-356.

25. Grimby G, Saltin B, Wilhelmsen L. Pulmonary flow-volume and pressure-volume relationship during submaximal and maximal exercise in young well-trained men. Bull Eur Physiopathol Respir 1991; 7: 157-168.

26. Bernasconi P, Kohl J. Analysis of co-ordination between breathing and exercice rhythms in man. $J$ Physiol (Lond) 1993; 471: 693-706.

27. Dreyfuss D, Saumon G. Role of tidal volume, FRC, and end-inspiratory volume in the development of pulmonary edema following mechanical ventilation. Am Rev Respir Dis 1993; 148: 1194-1203.

28. West JB, Mathieu-Costello K. Pulmonary blood-gas barrier: physiological dilemma. News Physiol Sci 1993; 8: 249-253. 